\title{
PUERTO RICAN LAND REFORM: THE HISTORY OF AN INSTRUCTIVE EXPERIMENT
}

THE spectre of Castroism lingering long on our doorstep has focused the anxious attention of the United States on Latin American problems. Mixing self-interest with humanitarian motives, the United States has committed itself heavily to backing the Alliance for Progress as an instrument for preventing the spread of Communism in the Western hemisphere while bettering the sorry living conditions of the working classes. Among the broad social and economic reforms which it hopes to induce in member countries, the Alliance has attached high priority to tenurial reform and agricultural improvement. ${ }^{1}$ But land tenure reform-large scale changes in existing tenurial patternsis more complicated an issue than is indicated by its advocates, who often project an idyllic Jeffersonian view of nations of yeoman farmers as both their political and their economic goal. ${ }^{2}$ In areas where large scale farming is required to maximize productivity, the political goal of widespread farm ownership conflicts with the economic goal of maximum productivity. And in parts of Latin America, ${ }^{3}$ particularly those areas dominated by plantation latifundia, ${ }^{4}$ the political demand for land reform may represent not so much a craving for land by would-be farmers as a desire for "social justice" by a "rural prole-

The Yale Law Journal thanks Professor Charles Reich of the Property Division for bringing this paper to its attention.

1. See Raushenbush, The Challenge to the Alltance for Progress 31-32 (1962) ; Comment, The Chilean Land Reform: A Laboratory for Alliance-For-Progress Techniques, 73 Yale L. J. 310 (1963).

2. See Carroll, Land Reform as an Explosive Force in Latin America, unpublished paper presented to the Seminar of the Joint Committee on Latin-American Studies of the American Council of Learned Societies and the Social Science Research Council, JulyAugust, 1963, pp. 4, 5, 11. The goals of tenure policy are often only dimly visualized in terms of economic development. The emphasis is on demolition of the latifundia, with little exploration of alternative models beyond a vague notion of "family farming," which it is hoped will somehow promote the frequently announced aim of economic development. Carroll, The Land Reform Issue in Latin America, in Latin American Issues, Essays AND CoMinents 197 (Hirschman ed. 1961).

3. There are a variety of definitions and uses of the term "Latin America." It is used here in its broad geographic sense to include South and Central America and the Caribbean. This region, once claimed by Spain and Portugal, had a common colonial background, generally speaks a language with a common root, has a predominantly common religion, and has generally had a parallel development of national institutions.

4. The agrarian structure of much of Latin America is characterized by latifundia, large landed estates, and minifundia, tiny farms. Two basic types of latifundia dominate Latin-American agricultural life-the hacienda and the plantation. Typically, the hacienda is an inefficient, thinly capitalized, sprawling estate, with a quasi-feudal relationship between the landowner and tenant families. On the other hand, the plantation is an efficient and highly capitalized commercial enterprise. See Mintz, La Plantacion Y La Refarma Agraria, 2 Revista Interamertcana de Cienctas Soctales 62, 63-69 (1963); Wolf \& Mintz, Haciendas and Plantations in Middle America and the Antilles, 6 Socral \& EcoNoMIC STUdIEs 380 (1957). 
tariat" which can be mollified without recourse to extensive fragmentation and redistribution of large estates.

Assuming that speedy economic development is the primary goal of Latin American statesmen, this essay will examine the history of land reform in Puerto Rico, to learn how-in at least one instance-political drives have been bent to the service of economic goals. In Puerto Rico, the only Latin American polity with an experience with peaceful land reform in existence long enough to be studied profitably, ${ }^{\mathfrak{B}}$ politicians and planners sincerely devoted to widespread tenurial reform as their principal developmental program concluded that it was both economically desirable and politically possible within this aim to subordinate redistribution in individual farms, which they originally felt necessary to satisfy rural sentiments, to a tenurial reform program designed to maintain the productivity and efficiency of the plantation latifundia. Subsequently, these same statesmen were led to the conclusion that their primary goal of speedy economic development could be achieved only by subordinating their avidly pursued tenurial reform program to industrial development. An analysis of the reasons for the decision to shift governmental efforts away from the creation of large numbers of individual farms (and later away from an imaginative tenurial reform program) and of the results of the shift suggests a need for reassessing the priority status attached to land reform. The disenchantment of Puerto Rican planners with land reform is all the more striking because a combination of factors created a climate highly favorable to the successful implementation of land reform at the time their program-the Land Law of $1941^{7}$-was inaugurated.

Land tenure reform had a legitimacy in Puerto Rico generally lacking in Latin America. As early as 1900, soon after the United States acquired Puerto Rico, the United States Congress had sought to prevent corporate land concentration by passing what has become known as the "500 Acre Law." statute provided that the charter of every corporation authorized to engage in

5. The term was coined by Professor Mintz to describe the landless, wage-earning, store-buying, and corporately employed workers in a plantation system. See Mintz, The Folk-Urban Continum and the Rural Proletarian Community, 59 AMr. J. Socrology 139 (1953). The rural proletarian never formed the peasant-type attachment to the land, and his aspirations were more geared to better wages and conditions of employment in his open-air factory than to becoming an independent farmer. Ibid.; Mintz, Cañaneiar: The Subculture of a Rural Sugar Plantation Proletariat, in The People of Puerto Rico 314, 338-50 (Steward ed. 1956).

6. Only Mexico, which began its sweeping program in 1917, has had a longer experience with agrarian reform in Latin America than Puerto Rico. Not until 1953, when Bolivia launched its reform program, did another Latin American country make significant experiments with modern agrarian reform measures. But the experiences of Mexico and Bolivia can hardly be characterized as peaceful experiments. For the story of the Mexican reform, see Tannenbaum, The Mexican Agrarian Revolution (1930), and for the Bolivian reform, see Patch, Bolivia: U.S. Assistance in a Revolutionary Setting, in SocraL Change in Latin Adrerica Today 108 (1960).

7. 28 L.P.R.A. \& 241 (1955).

8. 31 Stat. 716 (1900). 
agriculture in Puerto Rico must restrict ownership and control of land to 500 acres. ${ }^{9}$ However, the only attempts at enforcement had come from a few registrars, subsequently frustrated, who refused to record conveyances where the grantees were, or would be, notoriously violating the law. ${ }^{10}$ Chiefly re-

9. No corporation shall be authorized to conduct the business of buying and selling real estate or be permitted to hold or own real estate except such as may be reasonably necessary to enable it to carry out the purposes for which it was created, and every corporation hereafter authorized to engage in agriculture shall by its charter be restricted to the ownership and control of not to exceed five hundred acres of land, and this provision shall be held to prevent any member of a corporation engaged in agriculture from being in any wise interested in any other corporation engaged in agriculture.

31 Stat. 716 (1900).

Several aspects of the language of the Resolution are worth noting. The 500 acre restriction applies only to corporations. Alternate modes of control and operations, such as partnerships, proprietorships, and trusts were not included within its short sweep. Corporations were not prohibited from acquiring more than 500 acres of land; corporate charters were simply required to contain a clause limiting land acquisition to 500 acres. Moreover, no penalty was provided for violation of the law. This Joint Resolution was the outgrowth of debate on President McKinley's free trade bill for Puerto Rico. Republicans were responsible for amending the bill in Committee to provide for a tariff of $25 \%$ of the regular tariff rate on trade with Puerto Rico. The Democrats, charging that the Hawaiian and continental sugar interests had pressured the Republicans away from the President's free trade position, proceeded to make the amendment a sizeable issue. The controversy resulted in a reduction of the tariff from $25 \%$ to $15 \%$ of the regular rate and in its duration being limited to two years.

The mainland sugar interests were not concerned about competition from existing Puerto Rican sugar producers, whose crop amounted to only about 70,000 tons, but they were worried that large investments would enter Puerto Rico and greatly expand its sugar production if free trade went into effect. See Report on the "Five Hundred Acre Law," in Tugwell, Puerto Rican Public Papers 291, 296-99 (1945). Tugwell maintains that the most tenable theory to explain the 500 acre limitation is to attribute "the prohibition to the lobbyists and the legislators from other areas of sugar production." Id. at 296. But Tugwell overstates his case, for important support for the Joint Resolution came from Congressmen who felt simply that the United States had a moral obligation to prevent large trusts from acquiring the best lands of the small island. See De Gracia, The Land Authority of Puerto Rico, 12 GEO. WASH. L. Rev. 302, 303-04 (1944). The 500 acre restriction represented a compromise annong those interested in protecting mainland sugar interests from potential Puerto Rican competition, those moral idealists interested in preserving an imaginary vision of yeoman farmers from displacement by large trusts and agrarian monopolies, and those concerned that there would be no development of Puerto Rico if corporations were entirely banned from Puerto Rican agriculture.

10. The Supreme Court of Puerto Rico discouraged such attempts by holding that these registrars had exceeded the scope of their authority in refusing to record conveyances, even if the deed on its face violated the 500 acre restriction. Compañia Azucarera de Carolina v. Registrar of Property, 19 PR.R. 143 (1913); Compañía Azucarera del Toa v. The Registrar, 19 P.R.R. 724 (1913); Baetjer v. Registrar of Property, 48 P.R.R. 627 (1935). The peculiar phraseology of the 500 Acre Law led quite naturally to the conclusion that "the Attorney General is the exclusive officer in whom is confided the right to . . . attack the right of a corporation to hold land." Compañia Azucarera de Carolina v. Registrar of Property, 19 P.R.R. 143, 152 (1913). 
sponsible for nonenforcement were the large, American-owned sugar companies, four of which controlled 177,000 acres of the island's most fertile land -more than a quarter of the land suitable for continuous cultivation. ${ }^{11}$ The sugar companies directly employed approximately 20 per cent of the labor force and exerted great political pressure through a variety of measures, including the purchase of votes, curtailment of credit at company stores, evictions from company land, and a high powered Washington lobby. ${ }^{12}$ Despite its desuetude, and the fact that it may have been intended more to curb mainland sugar trusts than to prevent large-scale land holdings on the island, the presence of the 500 Acre Law enabled groups concerned with land reform in the 1930's to manipulate the symbols of law and order to achieve a measure of respectability for an otherwise radical program.

During the decade of the depression, abysmal living conditions heightened the discontent of Puerto Rico's rural proletariat, who comprised about 80 per cent of the population. ${ }^{13}$ And the island's frustrating experience with the 500 Acre Law, demonstrating the futility of a statutory restriction on the latifundia when enforcement was entrusted to those within the influence of the latifundistas, indicated the necessity for bringing new political groups to power before a land reform program could be instituted. ${ }^{14}$

11. See Report of Esteban A. Bird, pp. 53-61, quoted in Record, pp. 268-77, Puerto Rico v. Rubert Hermanos, Inc., 309 U.S. 543 (1940).

12. Ibid.; Diffie \& Diffie, Porto Rrco: A Broken Pledge 45-81 (1931).

13. See Clark, Porto Rico and Its Problems 13 (1930); Diffie \& Diffie, op. cit. supra note 12, at 5. Per capita income slid from the none-too-towering heights of $\$ 122$ in 1929-30 to $\$ 86$ in 1932-33. Perioff, Puerto Rico's Economic Future 30-31 (1950). By the summer of 1934 approximately 350,000 of the labor force was unemployed, affecting an estimated 75\% of the population. Information Research Secrion, Facts About the Puerto Rico Reconstruction Administration 4 (1938).

14. Benjamin Horton, the Attorney General of Puerto Rico, was less than enthusiastic about the prospect of enforcement of the 500 Acre Law in 1937. When enforcement was suggested to him by New Deal administrators, Horton's office issued a memorandum asking the following questions: (1) What is a corporation? (2) What does the word "control" mean? (3) Who is to enforce the law? (4) Is the law worth enforcing anyway? Horton suggested the restriction be raised from 500 to 6000 acres and sent an assistant to the sugar corporations to secure arguments against the advisability of the law. MAtHEws, Puerto Rucan Politics and the New Deal 216 (1960).

The memorandum made it painfully clear that little cooperation could be expected from Horton in enforcement of the 500 Acre Law, and Dr. Gruening, Director of the Division of Territories and Island Possessions, worked quietly to secure Horton's removal and replacernent by Benigno Fernández Garcia, the first Puerto Rican to hold the post of Attorney General. Ibid. The Union-Socialist coalition, which controlled the insular legislature, was upset at the appointment of Fernández Garcia, a distinguished member of the minority Liberal Party and a man outspokenly in favor of immediate enforcement of the 500 Acre Law. The legislature cut the appropriation for the Attorney General's Office in the hope that a shortage of funds would prevent enforcement of the law, but the Puerto Rican Reconstruction Administration, a federal relief agency, paid the costs of litigation to enable the Attorney General to enforce the 500 Acre Law. Gándara, LAND and LIBERTY 12 (1943).

Fernández Garcia promptly set about enforcing the 500 Acre Law by filing quo warranto proceedings against several of the large sugar corporations. A Puerto Rican cor- 
Drawing upon and responding to the political atmosphere created by this rural discontent and frustration, Luis Muñoz Marín founded a new political party, the Populares. ${ }^{15}$ In 1940, in the party's first campaign, Muñoz stumped the countryside with a program calling for destruction of the sugar latifundia and restoration of land ownership to those who actually tilled the soil. ${ }^{16} \mathrm{He}$ complained loudly of the American-owned, "absentee" corporations who controlled the island's sugar fields, siphoning their profits off to the mainland.17 To the amazement of the major political parties, who had relied in large part on the traditional practice of purchasing votes, the reform-minded Populares attained control, albeit tenuous, over the insular legislature. ${ }^{18}$

The first important piece of legislation to issue from the Populare-controlled legislature was the much promised Land Law. ${ }^{19}$ The fundamental purpose of the Land Law was to end the corporate latifundia and to prevent their reappearance. $^{20}$ The effete 500 Acre Law was bolstered by extending the restriction on land ownership from corporation to "every artificial person,"21

poration, Rubert Hermanos, Inc., which operated 12,188 acres, was chosen as a test case. In July of 1938 the Supreme Court of Puerto Rico rendered judgment for the People of Puerto Rico, fined Rubert Hermanos, Inc. $\$ 3000$ and costs, and ordered the forfeiture of the corporate charter and the immediate dissolution of the corporation. People v. Rubert Hermanos, Inc., 53 P.R.R. 741 (1938). The First Circuit Court of Appeals reversed the judgment on the theory that acts of the Puerto Rican legislature which conferred jurisdiction on the Supreme Court of Puerto Rico to impose penalties for the violation of the federal 500 Acre Law were invalid because they attempted to amend and enlarge the scope of the federal law. Rubert Hermanos, Inc. v. Puerto Rico, 106 F.2d 754, 759 (1st Cir. 1939). The Supreme Court unanimously reversed, holding that the Organic Act, in which the 500 Acre Law had been incorporated in 1917, gave Puerto Rico the full power to legislate on matters of local concern, and "nothing more immediately touches the local concern of Puerto Rico than legislation giving effect to the Congressional restriction on corporate land holdings." Puerto Rico v. Rubert Hermanos, Inc., 309 U.S. 543, 548 (1940).

15. See Edel, Land Reform in Puerto Rico, Caribbean Studies, Oct. 1962, pp. 26, 29. The party's slogan was "Pan, Tierra y Libertad." Tugwell, The Stricken Land 7 (1947).

16. Edel, supra note 15 , at 30 .

17. See id. at $29-30$.

18. The Populares had a one vote majority in the Senate, and 17 out of 38 representatives in the House. A working arrangement with a minority party until 1943 made it possible for the Populares to control the House. Descartes, Historical Account of Recent Last Reform in Puerto Rico, in Portrait of a Soctety 168, 175 (Fernández Méndez ed. 1956).

19. 28 L.P.R.A. $\S 241$ (1955).

20. Statement of Motives, id.

21. This term was defined rather expansively by the statute:

[T] he term "artificial person" shall refer to private corporations, limited companies, societies, partnerships, joint-stock companies, voluntary associations . . . . business trusts, Massachusetts trusts, common law trusts, and any other form of corporate organization, or any other organization, partnership or entity created for the purpose of carrying out transactions or attaining specific objectives, which continue to exist regardless of the changes made among its members or among persons participating in them, and whose affairs are managed either by one person only, or by 
although it continued to exempt individual holdings. Largely absentee owned and controlled, corporate rather than individual latifundia were the symbols of Puerto Rico's social and economic ills to the Populares. The Land Authority, a public corporation to be set up in the Department of Agriculture and Commerce, ${ }^{22}$ was given a preferential right to purchase property sold by a receiver in quo warranto proceedings brought by the Attorney General for violations of the 500 Acre Law. ${ }^{23}$ Included within its broad authority were the powers to acquire and deal in property $;^{24}$ to reclaim swamp land; to borrow money; to issue bonds; to make crop loans; and to make its own rules relating to its activities. ${ }^{25}$ Subsequent amendments broadened these powers to cover such activities as the acquisition and operation of sugar mills and other agricultural processing facilities. ${ }^{20}$

The principal problem facing the Populares in enacting the 1941 law was what the Land Authority should do with the land it acquired. While the 500 Acre Law provided a clear basis for acquiring the land of the corporate latifundia, it offered no guidelines for redistribution. However, the planners of 1941 had a fund of experience with prior Puerto Rican land reform experiments on which to draw. The Homestead Commission, created by the insular legislature in 1921, had been attempting to create small independent farms by renting public lands to farm laborers. ${ }^{27}$ The typical homestead was only sixteen acres, and the combination of small acreage and infertile soil made it difficult for lessees to support their families from the farms. ${ }^{28}$ The Puerto Rican Reconstruction Administration, a federal relief agency, had also explored the feasibility of establishing individual farms. A pilot program of more than 600 farms, ranging in size from four to twenty acres, was organized dur-

a committee, a board, or any other group of individuals in a representative capacity, and any other association which is an artificial person.

28 L.P.R.A. § 401 (1955).

22. 28 L.P.R.A. § 242 (1955).

23. Laws of Puerto Rico 1941, Act No. 26, Section 23.

24. The central power granted the Authority was the power to acquire land through purchase, cession, transfer, exchange, lease, and condemnation. Laws of Puerto Rico 1941, Act No. 26, Section 8(9). The power of eminent domain was limited to the acquisition of property held in violation of the 500 Acre Law. Laws of Puerto Rico 1941, Act No. 26, Section 14. To acquire other property by condemnation, the Land Authority had to ask the Attorney General to institute eminent domain proceedings in the name of the People of Puerto Rico. People v. Saldaña, 68 P.R.R. 865, 867 (1948).

25. Laws of Puerto Rico 1941, Act No. 26, Section 8.

26. E.g., Laws of Puerto Rico 1946, Act No. 474.

27. See, Descartes, supra note 18, at 170 . Rivera Santos, Tennutre Innovation and Agricultural Production in Puerto Rico, in LAND Tennure 328, 331 (Parsons, Penn \& Raup eds. 1956).

28. Koenig, A Compremenstve Agricultural Program for Puerto Rico 248 (1953). There were frequent assignments of holdings and rents were difficult to collect. Packard, The Land Authority and Democratic Processes in Puerto Rico, InTER-AnIERICAN EcoNomic AfFaIRs 49, 91 (1948). The program was abolished in 1947, and its undistributed land was entrusted to the Land Authority. Laws of Puerto Rico 1947, Act No. 407. 
ing the mid-1930's. ${ }^{29}$ Though these farms were designed to be self-sufficient, administrators soon found it necessary to supply outside sources of income to enable the farmer and his family to survive. ${ }^{30}$ And in 1938 the Farm Security Administration, another federal agency, began a program to create selfsufficient farms. ${ }^{31}$ Though it gave seed and equipment to the new farmers, this agency worked primarily through loans, for it was not permitted to acquire land directly. At first it set a minimum farm size of twenty-five acres, but, after discouraging results in obtaining self-sufficiency, it raised the minimum to approximately thirty-five acres. ${ }^{32}$ By lending close to $\$ 5000$ per farm and by carefully selecting and supervising those few farmers fortunate enough to be chosen, it was able to establish a number of self-sufficient farms. ${ }^{3 \varepsilon}$

The Farm Security Administration's experience with the size farm required for self-sufficiency, revealed the massiveness of the task of Puerto Rican rural renewal. There was simply too little land, too many people, and too little money. With a land area of only $2,199,000$ acres and a population of more than $1,880,000,{ }^{34}$ Puerto Rico was one of the most densely populated regions of the world. And, unfortunately, many of the acres are far less fertile than the inhabitants. Much of the land is hilly and mountainous, and only 603,500 acres are considered usable for continuous cultivation. ${ }^{35}$ Moreover, even in 1941, a good deal of the soil's original fertility had deteriorated from intensive cultivation of a single crop and from poor soil cultivation techniques. ${ }^{36}$ Even if all the cultivatable land in Puerto Rico had been converted into 35-acre farms, fewer than 20,000 individual farms could have been created by the Farm Security Administration, at a cost of almost $\$ 100,000,000 .{ }^{37}$

New Deal administrators had also made an attempt to fashion a suitable alternative to small farming by setting up cooperatives. The large sugar companies had been arguing persuasively that large holdings were necessary in order to grow sugar cane efficiently. Only the larger farms had enough capital to avoid paying the exorbitant interest rates charged the small farmers, and only the large farmers employed advanced agricultural techniques and achieved large scale technological efficiencies. Puerto Rico had never been a low cost sugar producing area, and it could ill afford any drop in production or increase

29. Descartes, supra note 18 , at 173 .

30. Ibid.

31. Id. at 174 .

32. See Chandber of Comarerce of Puerto Rico, The Land Authortty of the GOVERNMIENT OF PUERTo RICo 46-49 (1945).

33. Ibid.

34. Center of Latin-American Studies, University of California, Los Amgeles, Statistical Abstract of LATIN-Anerica - 4, 10 (1962).

35. KoENIG, op. cit. supra note 28 , at 48 . Another 91,500 acres are classified as suited for occasional cultivation. Ibid.

36. Id. at 45,46 .

37. $\frac{695,000 \text { acres }}{35}=(19,857$ farms $) \times(\$ 5,000[$ FSA cost per farm $])=\$ 99,285,000$. 
in the costs of production; many feared that both would accompany enforcement of the 500 Acre Law. ${ }^{38}$ The Puerto Rican Reconstruction Administration (PRRA) had hoped that its experiment with cooperative farming would indicate a way to avoid these problems while permitting those who worked the land to share in its profits. In 1936, 10,400 acres of good cane land and a sugar mill, Central Lafayette, had been acquired from an absentee French family. The best lands of the Lafayette latifundia, 4500 acres, had been divided into twelve land cooperatives, each less than 500 acres, comprised of the men who actually worked the land. The PRRA loaned the cooperatives more than $\$ 4,000,000$ for the purchase of the land and for operating capital, taking mortgages on the land and the crops as security. ${ }^{39}$ The loans were to be repaid over a thirty year period from the profits of the farm. But the anticipated profits did not appear, and the financial situation of the cooperatives became so precarious that within three years the PRRA was forced to repossess and resell the farms. ${ }^{40}$

In resolving the redistribution issue, the Populares showed an awareness of these historical lessons, and of the economic aspects of land reform. Though Muñoz and his cohorts had long been proponents of widespread individual farm ownership, a realization of the potentially pernicious effect on productivity that implementation of this political goal might have, led them to enact a program dealing with the problems of tenurial reform on three distinct levels: (1) individual farms, (2) proportional profit farms, and (3) agregado resettlement.

There was a widespread expectation in 1940 that family farms would be the standard mode of redistribution. ${ }^{41}$ Consequently, despite the expensive experiences of the Homestead Commission, the PRRA, and the Farm Security Administration with family farms, the Populares still felt politically committed to include in the Land Law some provision directing the Land Authority to

38. See, e.g., Transcript of the INQutry by the Tugwell Group into the Struatron ARISINg from the ValdDation of the So-Called 500 ACre Law (1941).

39. Informition Research Section, Facts About the Puerto Rrco Reconstruction Adninistration 6, 7 (1938). The laborers pledged their voting rights to the P.R.R.A., who operated the 12 cooperatives as a unit under a management contract. Descartes, Land Reform in Puerto Rico's Program of Economic Advancement, in AckerMAN \& HarRIs, FaAmI FarM Policy 285, 293 (1946).

40. Descartes, supra note 18 , at 172 . The Lafayette experiment was poorly conceived. Most of the laborers who became cooperative owners were illiterate; few had any experience or instruction in the problems of management in the sugar industry. In addition to lacking any cooperative tradition, such as that of the Mexican ejido, the Lafayette laborers-turned-farmers were saddled from the start with a heavy debt load, which left them little more than they had earned as wages after the deduction of interest and amortization. The Lafayette experiment might have eventually worked out, given enough time and money, and it by no means proved that cooperatives were unfeasible in Puerto Rico. But its failure made the Populares leery of cooperative ventures in the sugar fields. See Hanson, Transformation, The Story of Modern Puerto Rico 144 (1955).

41. See Edel, supra note 15 , at 35 . 
set up individual farms. ${ }^{42}$ These farms were to vary from 10 to 100 acres, and were to be created on any Land Authority holdings not deemed particularly suitable for proportional profit farms. The Authority was given the power to rent the individual farms, to sell them outright, or to sell them to their lessees, crediting the rentals towards the purchase price. ${ }^{43}$ In 1948 the legislature substituted for the acreage restriction a restriction based on farm value-each farm unit was not to exceed $\$ 5000.44$ But concession to the popular desire for family farms was largely a symbolic matter. The Land Authority, perceiving that this traditional ideal of reform reallocated Puerto Rico's scarce land resources wastefully, utilized this section only as a token gesture towards fulfillment of the Populares' campaign promises. Not until 1944 were any individual farms set up,,$^{45}$ and by 1949 the number of individual farms organized by the

42. Laws of Puerto Rico 1941, Act No. 26, Section 25.

43. Laws of Puerto Rico 1941, Act No. 26, Sections 25, 27. Despite this mandate, the Land Authority distributed individual farms in usufruct for the life of the recipient.

44. Laws of Puerto Rico 1948, Act No. 224, now 28 L.P.R.A. \$§ 581-89 (1955). The amendment directed the Authority to continue its practice of granting only a life usufruct to the individual farmer for a reasonable rental. The usufruct is extinguished by the death of the usufructuary, but the Land Authority may grant the usufruct to a surviving spouse, surviving adult children, or a legal representative of surviving minor children. If the usufruct is not granted to a surviving wife or children, it reverts to the Land Authority for redistribution. The Land Authority is required to impose a number of conditions in the usufruct contract:

(1) The usufructuary must live on and work the farm.

(2) The usufructuary may grow whatever he wishes on the farm, but he must follow the soil conservation and soil improvement practices recommended by the Land Authority.

(3) Failure to pay the rent terminates the usufruct. Should termination result, the only rights of the usufructuary in the farm are the rights to harvest a growing crop and to receive the value of any immovable improvements he has made with the Authority's consent.

(4) Nonagricultural businesses, such as bars or stores, may not be established on the farm.

(5) Employees of the Land Authority must be permitted free access to the usufruct for inspection.

(6) The usufructuary may not sell, transfer, or in any way encumber the farm without the consent of the Land Authority. Any attempted transfer vests no rights in the purported transferee and is grounds for the forfeiture of the usufruct.

45. See Autoridad De Tierras, Informe Annual Ano Naturai at 16 (1945-46). [Hereafter reports of the Land Authority will be cited as INFORME.] The Land Authority explained that:

In view of the fact that the objectives set up under Article 25 of the Land Law are very much like those being followed by the Farm Security Administrationa federal agency-the Land Authority of Puerto Rico is not giving great emphasis to this aspect of its program. Only such lands unsuitable for the establishment of proportional profit farms or of rural communities are devoted to family size holdings. Ibid, 
Land Authority had grown to only $291 .^{46}$ The concept of the individual farm was practically abandoned in favor of a more promising one-proportional profit farms.

The heart of the Land Authority's program, the proportional profit farm, was designed to assure the profits of the soil to its Puerto Rican tillers, who might hopefully develop a sense of ownership in the land, while avoiding the loss of efficiency and productivity which many feared would accompany the breaking up of the large sugar corporations. In conception, it was a unique blend of socialism and capitalism, preserving the profit motive for both management and labor, while ownership of the land remained in the Puerto Rican Government. The farms were to be organized in areas where considerations of efficiency made division of large estates inadvisable. The Authority was directed to rent farms of 100 to 500 acres (though larger farms might be leased if justified by efficiency) to qualified farm managers, who were to reside on the farm and manage it in return for five to fifteen per cent of its profits. The lessee-manager was granted the power to hire and fire employees, but was required to pay his employees the going wage rate in the area plus a proportion of the farm's net profits. ${ }^{47}$ Each employee's share was to be calculated in direct proportion to the total amount of wages paid that employee for his labor on the farm during the fiscal year. ${ }^{48}$

The concluding section of the Land Law represented a further attempt to improve the bargaining position of agricultural workers while appeasing the

46. INFORMIE, $1948-49$, p. 26 . Only 1533 of the 5000 acres comprised by these 291 farms were cultivated, and the estimated land value of each farm was only $\$ 680$.

47. 28 L.P.R.A. $\$ \S 461,463$ (1955). Unfortunately, privately managed proportional profit farms never materialized. The Land Authority soon found that no financially responsible person would lease land on which he had to accept the risk of loss, grant usufructs of small plots to the people living on the land, pay the going wage rate in the area, and restrict his profits to $15 \%$. Chassber of CoMmerce of Puerto Rico, op. cit. supra note 32, at 7. Rather than not organize proportional profit farms, the Land Authority hired experienced men to manage the farms and paid them a salary plus a share of the profits. In addition, the Authority agreed to assume financial responsibility for any losses of the farm. The Authority called these managers "lessees" because the Land Law directed that the proportional profit farms be rented, but these men were "lessees" in name only. Ibid.

While eminently sensible, the Authority's assumption of direct control was plainly ulira vires until 1946, when two amendments were made to the Land Law. The first provided that the lessee could be paid a current salary and a bonus of 1 to $10 \%$ of the farm's profits. Laws of Puerto Rico 1946, Act No. 272. The second amendment stated that "lessee" meant simply the person who administered the farm and did not have tenurial connotations. 28 L.P.R.A. $\$ 462$ (1955).

The Land Authority from the start has exercised almost complete control over the operation of the farm. The administrators or "lessees" are employees of the Authority and are responsible to regional supervisors. The Authority purchases fertilizer and seeds, rents and repairs the equipment used on the farms, supplies credit, handles the negotiation of collective bargaining agreements, and keeps all records and accounts of the farm's operation. The only responsibility of the administrator is the direct supervision of the workers and day-to-day management. See KoENIG, op. cit. supra note 28, at 252.

48. 28 L.P.R.A. § 463. 
desire of the multitudinous agregados, landless rural families, for their own homesites. Prior to 1941, four out of five rural families owned no land, paid no rent, and were subject to eviction at the whim of the owner of the land where they squatted. ${ }^{99}$ The announced purpose of this final section was "to promote the welfare and economic freedom of, and to do social justice to, agregados." 50 Its theory was that it is a "fundamental human right of all the human beings who live exclusively by the tilling of the soil, to be the owners of at least a piece of that land which they may use to erect thereon ... their own homes, thereby delivering them from coercion and leaving them free to sell their labor through fair and equitable bargaining." 51

The Land Authority was directed to construct neighboring rural communities consisting of twenty-five to five hundred agregado families each. ${ }^{52}$ Originally, the Land Law required the Authority to distribute to agregados parcels varying from one-half to one acre, but subsequent amendments permitted the Authority to distribute smaller parcels in areas adjacent to urban zones, and larger ones in infertile rural areas. ${ }^{53}$ There was to be no discretion involved in granting a parcel; if the applicant complied with the statutory requirement, he was entitled to be awarded a parcel. However, if an agregado did not build or transfer his house to the parcel within ninety (more recently one hundred twenty) days of the grant, or if he attempted to convey or encumber his parcel without the consent of the Land Authority, his parcel might be revoked. ${ }^{54}$

This tripartite approach to tenurial reform reflected a well-conceived effort to deal at several levels with the problem of redistribution. But finding funds to finance the expropriation of the latifundia. was vitally important to effectuat-

49. Clark, op. cit. supra note 13 , at 13.

50. 28 L.P.R.A. § 551 (1954). Agregado is a commonly used but imprecisely defined Puerto Rican word. Section 555 of the Land Law defines agregado as "any family head residing in the rural zone, whose home is erected on lands belonging to another . . . and whose only means of livelihood is his labor for a wage. . ." There are three types of agregado. The first type works on a farm in exchange for a house and wages. The second type does agricultural jobs for wages, but lives beyond the borders of the farms where he works, on land which he does not own or rent. The third type corresponds closely to the American sharecropper. Like the first type of agregado, he works on a particular farm for wages and a house. In addition, he receives a plot of ground which he farms himself, sharing his small harvest with the landowner. Howell, Patterns of Rural Resettlement in Puerto Rico, in PLANNIng For Puerto Rico 39, 43 (Newman ed. 1945).

51. 28 L.P.R.A. \$ 241 (1955).

52. Laws of Puerto Rico 1941, Act No. 26, Section 74. The Authority was also directed to set aside lots for stores, medical centers, police stations, schools, community centers, and playgrounds. Though they authorized the Land Authority to promulgate sanitary regulations for the rural communities, the framers of the Land Law appeared to perceive the role of the Land Authority in resettlement as limited to planning sites, acquiring land, and distributing parcels. 28 L.P.R.A. \$§ 552, 554 (1955).

53. These amendments allowed the Authority to distribute parcels less than onequarter of an acre in areas adjacent to urban zones and up to three acres in unfertile rural areas. 28 L.P.R.A. $\$ \S 551,553$ (1955).

54. 28 L.P.R.A. $\$ 553(1955)$. 
ing the program, for the United States Constitution obligated Puerto Rico to pay full compensation before taking private property. ${ }^{55}$ An unexpected bonanza made funds available soon after the act's passage. During the Second World War Puerto Rico's exports of rum to the United States increased phenomenally, and the United States continued, as before, to remit to Puerto Rico all the excise taxes collected. The taxes remitted between 1941-46 amounted to $\$ 200$ million-more than one third of the total revenues of the Puerto Rican Government. ${ }^{56}$ Additional American funds, totalling more than $\$ 530$ million, were injected into the Puerto Rican economy during the war years in the form of military expenditures. ${ }^{57}$

In short, conditions in Puerto Rico seemed most opportune for the implementation of a land reform program. Funds were available. Bona fide planners had drawn on substantial pools of locally obtained experience in designing a comprehensive and fairly well conceived land law, and a party dedicated to its enforcement was in power. To most observers, the first five years of the Land Authority's operation glowed with promise. ${ }^{58}$ But at this point, the Populares began a slow, yet accelerating, withdrawal from the elaborate program established by the Land Law. Between 1948 and the present, the Land Authority has acquired no additional land and the resuscitated 500 Acre Law has once more been relegated to the statutory scrap heap..$^{50}$ Plainly, by 1947 the Populares had realized that their tenurial program, even with the formation of proportional profit farms, was bringing Puerto Rico little closer to their primary goal of full employment with higher living standards. And they realized the political pressures for social change were insufficient to compel a full-scale program of dubious economic wisdom. Henceforth, the attention of the Populares has been riveted upon the economic possibilities presented by the island's industrialization.

Certainly there are historical reasons peculiar to Puerto Rico which partially account for the reversal in the Populares' attitude. Demobilization after World War II meant a loss of wartime revenues and a sharp drop in employment. ${ }^{60}$ The budgetary surplus from the extraordinary rum taxes had been

55. But query whether a statute making violation of the 500 Acre restriction a criminal offense and providing for forfeiture of land held in excess of 500 acres as a penalty would be considered a valid exercise of the police power or a "taking" of property requiring compensation, particularly if existing violators were given a reasonable opportunity to divest themselves of unlawfully held land?

56. Perloff, op. cit. supra note 13, at 114-17; Puerto Rico Industrial Dev. Co., ANNUAL REPORT at 4, 5 (1948).

57. Jaffe, People, Jobs and Economic Develophient 43 (1959).

58. See, e.g., Packard, supra note 28 , at 53.

59. 768 acres, whose purchase was arranged before 1949, were acquired by the Land Authority in 1949, but for all practical purposes, acquisitions ceased in 1948. See INFORME, 1948-49, at 15. The wave of land acquisition by the Authority crested at 102,400 acres. See KOENIG, op. cit. supra note 28 , at 252 .

60. Edel, supra note 15 , at 55 . 
quickly consumed, and Puerto Rico's financial resources were sorely limited.91 Also by this time, the political pressures for land reform had been largely dissipated. The desire for tenurial reform was chiefly a manifestation of dissatisfaction with the power and practices of the large sugar companies, rather than a desire by the agregado for a farm of his own. ${ }^{62}$ While a few of the sugar companies had had their lands expropriated, ${ }^{63}$ the majority of the companies were curbed in other ways-by regulation of them as public utilities, ${ }^{\text {,4 }}$ by passage and enforcement of minimum wage laws, ${ }^{65}$ and by termination of their disparate tax treatment. ${ }^{66}$ And agregado resettlement plus legislation protecting homesteads mitigated fear of company evictions.

In the absence of strong political pressures for land redistribution, the Populares, starkly confronted with a drastic shortage of insular resources, could chart their future course in economic terms - how best to allocate governmental efforts for the island's development. The island's population had far outgrown any likelihood that agriculture could serve as a viable basis for a national economy. ${ }^{67}$ Productivity rates, which would be jeopardized by further fragmentation of landholdings, were already dangerously low. ${ }^{68}$ Furthermore, substitution of mechanized for antiquated methods of farming was necessary if productivity was to be improved. ${ }^{69}$ Yet mechanization necessarily implied larger land holdings ${ }^{70}$ and a smaller agricultural work force.

While large enough to achieve the economies of scale needed for improved agricultural productivity, even the proportional profit farms found mechanization difficult. When a government engages in agriculture in overpopulated and underemployed areas, its reluctance to invest in machinery is considerable, for dislocated and unemployed agricultural workers represent votes. The proportional profit farms were not only reluctant to mechanize and modernize

61. Id. at 56.

62. Cf. id. at 53,54 .

63. Of the 33 corporations which held more than 500 acres, seven were subjected to expropriation, while five others sold part or all of their land to individuals. Edel, Land Reform in Puerto Rico, Caribbean Studies, Jan. 1963, p. 48.

64. Laws of Puerto Rico 1942, Act No. 221, at 1176.

65. See Andic, Income of Wage Earner Families and Economic Development of Puerto Rico, Caribbean Studies, Jan. 1963, pp. 14, 26; Mintz, Worker in tre Cane 186 (1960).

66. Compare Diffes \& DIFFIe, op. cit. supra note 12, at 51-62, with Packard, supra note 28 , at 81,82 .

67. See Baer, The Puerto Rican Economy and United States Economic FlucTUATIONS 11 (1962).

68. Candelas, Some Effects of the Sugar Programs on the Sugar Industry of Pucrto Rico, University of P.R. Agric. Experiment Station, Bull. 151, Oct. 1959, pp. 9-13.

69. KoEnIG, op. cit. supra note 28, at 178. In 1956 Puerto Rico employed 130,000 field workers at the peak of the season, to produce about the same amount of sugar as Hawaii did with 9,500 field workers. Candelas, supra note 68 , at 12 .

70. The estimated minimum size holding to make mechanization practicable in Puerto Rico is 800-1000 acres. See 1 Perkins, Credit and Related Problems in the AgruculTURE OF PUERTo Rrco 95 (1956). 
outdated agricultural methods, but also hired more workers than were needed and permitted a good deal of featherbedding. ${ }^{71}$ As a result of the failure to mechanize, and high management costs, the total profits of the farms were disappointing when compared with the large profits of the sugar companies before $1940 .^{72}$ From 1944 to 1948 , the proportional profit farms earned $\$ 544$,000 , less than the United States paid these farms for quota sugar under the Sugar Act in 1948 alone. ${ }^{\mathbf{7 3}}$ When the price of sugar began to fall in 1947, as sugar producing areas such as the Philippines and Hawaii began to resume normal exports after the war, some of the farms had substantial losses. The bulk of the losses, which amounted to $\$ 353,000$ in 1948,74 is attributable to prohibitive labor costs, poor sugar yields, and poor management.

The Populares began to realize that the proportional profit farms were to a large extent performing a make-work function analogous to that performed by some of the New Deal agencies in the United States, such as the Civilian Conservation Corps or the Works Progress Administration. The cost of subsidizing this alternative form of relief fell almost entirely on the poor agricultural worker, since the profits of the farms were distributed in direct proportion to the wages each worker earned. ${ }^{75}$ The Populares also realized that little could be expected from agriculture in supplying more jobs for the large number of unemployed, given the need for mechanization. Furthermore, the scarcity of funds made it difficult to justify continuing the sizeable expenditures involved in the complex of land reform activities. It became increasingly apparent that little would be produced on agregado plots and individual farms without sizeable aid in the way of credit, fertilizer, seed, equipment, marketings, and education in improved agricultural techniques. Successful agrarian reform required far more than expenditures for the redistribution of land. And land tenure reform was clearly not an answer to Puerto Rico's developmental needs.

71. The Authority's average labor cost per hundred weight of sugar from 1945 to 1949 , exclusive of the additional wages paid in distributed profits, was $\$ 2.41$, compared with $\$ 2.26$ for the large private producers during the same period. KoENIG, op. cit. supra note 28, at 256. Union contracts of the Land Authority prohibited the use of herbicides to preserve weeding jobs, and the Authority was unable to use mechanical weeders which it had purchased because of fear of worker resentment. Padilla Seda, Nocorá, The Subculture of Workers on a Government-Ozened Sugar Plantation, in The People of Puerto Rico 265, 281 (Steward ed. 1956). Moreover, the Authority often employed two or three times as many workers as it needed. Id. at 267.

72. Edel, supra note 15 , at 58 .

73. See INFORARE, $1948-49$ at 35 . In 1948 only three of the 48 proportional profit farms would have had profits without the United States sugar subsidy. Ibid.

74. Id. at 13 .

75. Thus, the practice of making and spreading work on the proportional profit farms acted as an aggressively regressive tax. For example, of the 2,233 persons employed in 1946 on San Francisco, the largest proportional profit farm in the Cambalache project, 1,369 employees earned less than $\$ 50,550$ earned between $\$ 50$ and $\$ 250$, and only three earned more than $\$ 1000$. Packard, supra note 28 , at 85 . 
As early as 1942 the Populares had begun to explore the possibilities of developing new industry for Puerto Rico. At that time Puerto Rico's industry consisted almost entirely of cottage industry and factories which prepared agricultural products for sale. ${ }^{76}$ In launching the Puerto Rican Industrial Development Company (PRIDCO) and the Puerto Rican Development Bank in 1942, the Populares hoped not only to create new sources of income, but also to satisfy some of the pressing demand for manufactured goods which the mainland was unable to supply because of the war. ${ }^{77}$ And Puerto Rico desperately needed both glass and paperboard factories during the early 1940's if it was to package its vastly increased rum output. ${ }^{78}$ But vigorous efforts by the newly formed PRIDCO to persuade private United States or Puerto Rican capital to build these plants proved fruitless, largely because of wartime scarcities of personnel and supplies. ${ }^{79}$

The administrators of PRIDCO then decided that industrialization could best be stimulated by direct government action. It was hoped that if the government primed the pump by building and operating some of the necessary manufacturing plants, private capital would be encouraged to follow suit. ${ }^{80}$ PRIDCO constructed and operated a glass plant, shoe factory, paperboard products plant, and clay products plant. It also acquired an operational cement plant from the PRRA. ${ }^{81}$ The cement plant proved profitable. But by the time the glass and paperboard factories were in production, the post-war slump in rum sales had reduced demand for their products well below their capacity. And the shoe plant priced itself out of the market by producing too many styles in short runs. ${ }^{82}$ It was soon obvious that the Puerto Rican Government lacked the managerial expertise, the marketing know-how, and the funds to industrialize the island by itself. The hoped-for number of new jobs failed to materialize. And the socialist tinge which these activities cast on the government discouraged rather than encouraged United States capital from investing in Puerto Rico. ${ }^{83}$

In 1947, as a result of all these developments, the Populares dramatically altered their policy towards industrialization. The emphasis that had been

76. See PerLoff, op. cit. supra note 13, at 97; Governarent of Puerto Rico, DEpartment of Agriculture and Comarerce, Puerto Ruco Industrial and Comarerctal 30 (1938).

77. See Stead, Fomiento-The Economic Development of Puerto Rico 13-15 (1958).

78. Hearings Before the Special Investigation Subcommittee on Investigations of Minimum Wages and Education in Puerto Rico and the Virgin Islands of the House Committee on Education and Labor, 81st Cong., 1st Sess. at 1-3 (1949) (Statement of Teodoro Moscoso, $\mathrm{Jr}_{\mathrm{r}}$ ) [hereinafter cited as Hearings].

79. Ibid.; Puerto Rxco Industrial Developmient Company, Annual Report 4 (1948).

80. BAER, op. cit. supra note 67 , at 12 .

81. Ibid.

82. Address by Teodoro Moscoso, International Industrial Development Conference, San Francisco, California, Oct. 17, 1957, quoted in STEAD, op. cit. supra note 77, at 15.

83. BAER, op. cit. supra note 67 , at 12. 
placed on land reform was shifted into "Operation Bootstrap"-an all out effort to attract private industry. To dispell the socialist aura of the Populare administration, the state owned industrial plants were sold to private entrepreneurs, ${ }^{84}$ and appropriations to the Land Authority for further expropriations were cut off entirely. ${ }^{85}$ The Populares recognized that Puerto Rico, an agricultural island with almost no mineral resources, little power, a paucity of skilled personnel, and a location far from mainland markets and supplies, would have to present special inducements if it were to be industrialized; they determined to do everything possible to create a climate favorable for new industry.

To some degree, Puerto Rico's relationship to the United States posed a barrier to this attempt. Traditional methods such as tariff protection were essentially unavailable, for the overwhelming bulk of Puerto Rico's imports of manufactured goods came from the United States, ${ }^{86}$ and Puerto Rico was powerless to erect a tariff barrier to United States goods. But Puerto Rico's special relationship to the United States was a two-edged sword, far sharper on one side than the other. If United States manufacturers had free access to the Puerto Rican markets, it was also true that Puerto Rican manufacturers had free access to United States markets. ${ }^{87}$ Political subordination to the United States greatly reduced investors' fears of uncompensated expropriation, extravagant taxation and regulation, or other interference with their funds. ${ }^{88}$ This subordination also obviated the need for some expenditures (e.g., military) common to national governments, and secured subsidies which might not otherwise be available. ${ }^{89}$ And the deeply ingrained American principle of no taxation without representation produced another plus : residents of Puerto Rico were relieved from the payment of federal income taxes. ${ }^{90}$ With a favorable insular tax structure, the tax advantages to American corporations of accumulating earnings in a Puerto Rican subsidiary would be substantial. ${ }^{91}$

84. See id. at 14.

85. The Authority's last big purchase was the holdings of Russell \& Co., the landowning partnership for the South Porto Rico Sugar Company. The sale was completed in 1948. When the Authority turned to the legislature for the bulk of the $\$ 5,753,000$ purchase price, it was met with a provision requiring the Land Authority to reimburse the Treasury of Puerto Rico with the full amount of the $\$ 4,600,000$ appropriation within one year. Laws of Puerto Rico 1948, Act No. 41. This was the first time the Land Authority had ever received an appropriation in the form of a loan, and it was the last legislative appropriation to the Authority for land acquisitions. By 1949 the Attorney General's Office no longer made any effort to enforce the 500 Acre Law by filing quo warranto actions. Edel, supra note 15 , at 59 .

86. PERLOFF, ap. cit. supra note 13 , at 139.

87. Id. at $143,144$.

88. See STEAD, op. cit. supra note 77, at 110-11.

89. See JAFFe, op. cit. supra note 57 , at $27,28$.

90. INT. REv. CoDE of 1954, § 933.

91. See Rudick \& Allan, Tax Aspects of Operations Under the Puerto Rican Excmption Program, 7 TAX L. REv. 403 (1952). 
This possibility for designing tax incentives was rather fully exploited. The Industrial Tax Exemption Act of 1947 extends complete tax exemption from income, property, and miscellaneous taxes and license fees to a broad group of qualified industries. ${ }^{92}$ The original act and its amendments make it possible for qualified businesses to avoid taxation during the first decade of their operations in Puerto Rico. Qualified businesses include industries whose products were not manufactured in Puerto Rico prior to January 2, 1947 and expansions of "designated industries" which the legislature considers to have good development prospects-generally labor intensive industries..$^{93}$

Supplementing the tax exemption program were a number of other efforts of the Puerto Rican Government to create a climate conducive to industrial development. The Government Development Bank extended credit on liberal terms, ${ }^{94}$ and PRIDCO built and leased factory plants at moderate rentals. ${ }^{95}$ In 1950 PRIDCO was incorporated into the Economic Development Administration (EDA), which became the co-ordinating and planning organ for industrial growth. ${ }^{96}$ EDA performs extensive research, provides useful information for potential investors, and engages in extensive promotional work in the United States. It screens and trains workers and provides such technical services as installation of machinery and equipment for new industrialists. ${ }^{.7}$

The results of Puerto Rico's industrial development program have been astonishingly successful. Since its inception, more than 750 plants have located in Puerto Rico. ${ }^{88}$ Their combined investment constitutes more than a half billion dollars ; 99 they directly employ more than 46,000 people. ${ }^{100}$ In the early years of the program, the bulk of the plants were labor intensive industries, such as textiles and apparel, attracted by the substantial wage differential as much as by tax exemption. ${ }^{101}$ But in recent years a substantial number of capital intensive industries, such as metal products, chemicals, and petroleum, have come to Puerto Rico. These capital intensive industries have required employees with greater technical skills and have done much to boost insular wage levels. ${ }^{102}$ The income generated by the once predominant agricultural sector of the economy has been far surpassed by income from manufacturing. ${ }^{103}$ From 1947 to 1958 Puerto Rico's gross product more than doubled, while

92. Laws of Puerto Rico 1947, Act No. 346, as amended, 13 L.P.R.A. $\$ 221$ (1955).

93. Ibid. As a matter of policy, tax exemption has been denied to firms which would close down plants in the United States to move to Puerto Rico. Hearings, supra note 78, at 3.

94. STEAD, op. cit. supra note 77, at 54 .

95. Id. at 37.

96. Id. at 25 .

97. Id. at 29-36.

98. Puerto Rico Planning Board, Economic Report to the Governor 11 (1960).

99. BAER, op. cit. supra note 67 , at 15 .

100. Puerto Rico Planning Board, op. cit. supra note 98, at 10.

101. See BAER, op. cit. supra note 67 , at 21 .

102. Cf. id. at 23 .

103. Puerto Rico Planning Board, op. cit. supra note 98, at 2. 
per capita income rose by more than 80 per cent ( 59 per cent in real terms), giving Puerto Rico a higher per capita income than any Latin American country. 104

The most apparent deficiency in the program has been its failure to spur local enterprise. ${ }^{105}$ Close to 80 per cent of the investment in manufacturing plants has come from external sources, ${ }^{106}$ and most of the new manufacturing ventures have been branches or subsidiaries of existing mainland firms. ${ }^{107}$ Local firms have had trouble breaking into mainland markets, for they have lacked familiarity with market conditions and have generally been inferior to mainland firms in design, packaging, quality control, and in ability to adapt to changing demands. ${ }^{108}$ As a result, they have had to restrict themselves to competing with mainland firms for shares of local markets.

Significantly, the Populares' choice of an industrialization program over the short range goals of dismantling the sugar latifundia and redistributing their estates has not meant continued rural discontent. As has been seen in the first years of their program, the Populares were able to dissipate the emotional fervor of rural workers for widespread land reform, as potentially explosive in Puerto Rico in 1940 as it is in many parts of Latin America today, without substantial diminution of the holdings necessary to retain essential economies of scale, through severe limitation of the power of the sugar companies. Rural discontent, moreover, found a release in unrestricted migration to the United States. From 1946 to 1957, close to 500,000 Puerto Ricans have migrated to the United States. ${ }^{109}$ Peak season labor shortages in the cane fields, resulting from these migrations, have encouraged mechanization of Puerto Rican agriculture. 110 Finally, the Populares averted renewed dissatisfaction by retaining some portions of the land reform program, particularly the agregado resettlement program, which was entrusted to a newly formed agency, the Social Programs Administration. ${ }^{111}$

104. BAER, op. cit. supra note 67 , at 15 .

105. See Puerto Rico Economic Development Administration, Stimulating Greater Local Investaient in Manufacturing Enterprises in Puerto Rico 11 (1960). Total local investment in manufacturing and the number of locally owned plants has increased, but the local share of private investment in Puerto Rico's industrial growth has declined from almost $18 \%$ in 1956 to $12.6 \%$ in 1959. Ibid.

106. Only $12 \%$ of the investment has come from local businessmen, while the Commonwealth Government has contributed 10\%. Id. at 15-16.

107. Id. at 17 .

108. Id. at 20.

109. Three-Monthly Economic Review of Cuba, Dominican Republic, Haiti, PuERTo Rrco 17 (June 1959). Many of these migrants were farm workers. Some of the cane workers, dissatisfied with seasonal employment, have moved to urban areas to seek jobs in Puerto Rico's burgeoning industry.

110. Personal Interview with Héctor Bayrón-Montalvo, Planning Director of the Puerto Rico Land Authority, Jan. 4, 1963.

111. 28 L.P.R.A. \& 521 (1955). This agency has taken an approach to agregado resettlement different from that of the Land Authority, which assumed that providing the 
With discontent quieted and investors reassured, Puerto Rico has significantly advanced its program of agricultural development. ${ }^{112}$ The Land Authority has begun to diversify its own agricultural programs, as the need for alternatives to sugar has become painfully apparent. The principal impetus came after 1953, when inclement weather, rising costs, and inefficient management rendered most proportional profit farms profitless. ${ }^{113}$ Pineapple has been seized upon by the Authority as the most suitable alternative to sugar. ${ }^{114}$

agregado with employment and a parcel of land would ipso facto end his quasi-serf-like status. Recognizing that land and employment, in minimal doses, were only a start in raising the dignity, civic utility, and the living standard of the former agregados, the Social Programs Administration has launched action programs to build community centers, co-operative stores, and medical centers, with some measure of success. Efforts have been made to extend public utility services and minimal sanitary facilities to resettlement communities. And the agency has initiated a crash program to build concrete houses to alleviate the severe housing problem. See Edel, supra note 63, at 28-30. By January of 1963, close to 60,000 families had been resettled in 334 rural communities, with relatively little drain on the Puerto Rican treasury. Puerto Rico Planning Board, Economia de Cuatros Anos, Anos Fiscales 1964-67. They have become part and parcel of the economic and social fabric of Puerto Rico, an integration which has been helpful to industrialization by expanding local markets. Prior to resettlement, the agregado bought almost no manufactured goods, for almost all his meager income was consumed for food. Increased wages and supplemental income from seasonal work in the United States has made it possible for many resettled workers to afford the purchase of some manufactured goods and enjoy appreciably better living conditions. Edel, sipra note 63, at 46 . The individual farm program has also been continued but in its same minor role.

112. The Puerto Rican Agricultural Company was created by the insular legislature in 1945 to develop new and better agricultural industries. With $\$ 10$ million in capital funds, the Agricultural Company initiated pilot supermarkets to sell local food products at reasonable profits, and conducted experiments with breeding beef and dairy cattle and with developing varieties of pineapple ideally suited to Puerto Rico. See Hibben \& PIco, Industrial Development of Puerto Rico and the Virgin Islands of the UnTted States 94, 168 (1948). In 1953 the functions of the company were entrusted to the Land Authority.

113. In 1953 a prolonged drought reduced total sugar production to 67,277 tons, about half the 1950 level, and the proportional profit farms had losses of $\$ 1,356,680$. INFORMIE, 1953 , p. 2. Private companies also decreased their production levels, but on the whole, weathered the storm, or lack thereof, far better than the Land Authority. E.g., Fajardo Sugar Co.'s production fell from 130,137 tons in 1952 to 109,293 tons in 1953, and its earnings dropped from $\$ 1,041,117$ in 1952 to $\$ 221,170$ in 1953. FaJARDo Sugar Co., ANNuAL RePORT to THE StOCKHOLDERS (1953). In 1954 heavy rains battered the cane fields, causing a net loss of $\$ 914,517$. InFORME, 1955, p. 4. By the end of 1956 the Authority had lost close to $\$ 5,000,000$ on the proportional profit farms. INFORME, 1956, p. 10.

The Authority has continued to lose money on the farms at a staggering rate. "Proportional profit" now seems a hopeful misnomer; many would be more appropriately termed "fincas de pérdidas perpetuas." Losses from 1958 to 1960 have averaged about $\$ 1,400,000$. INFORME, 1960, p. 6. Recent Planning Board figures indicate that the Authority lost a similar amount on the farms in 1961. See Economia de Cuatros Anos, Anos Frscales 1964-67, p. 130 (1962).

114. Pineapples had long been grown in Puerto Rico on a small scale, and the Puerto Rican fruit is excellent. Almost all the pineapple exports were of fresh fruit, for which 
Though it has been a losing venture for the Authority thus far, ${ }^{115}$ pineapple requires three times as many workers per acre as sugar and offers the possibility of high returns. A recent government joint venture with Stokely Van Camp, Inc. may capitalize on Stokely's expertise and marketing organization to turn pineapple into a profitable industry for Puerto Rico. ${ }^{116}$ In addition to the pineapple venture, the Authority has carried out several successful programs for increasing income and diversifying Puerto Rican agriculture: the stimulation of the beef and dairy cattle industry ;117 the reclamation of swampy

Puerto Rico's geographic proximity to the Eastern markets gave it an important competitive advantage on Hawaii. The Authority hoped to expand fresh fruit exports and to develop a canned pineapple industry that would effectively compete with the Hawaiian product for the United States market. The 1954 harvest brought the Authority a profit of $\$ 128,207$, INFORAIE, 1955, p. 11, and the Authority interested a number of small farmers in pineapple prospects. The Authority provided these farmers with seedlings, technical advice, and credit. The cannery, in which the Authority had invested in 1953, provided an outlet for their crop. See $i d$. at 10-12.

115. 1954 marked the peak altitude of the Authority's profits from growing pineapple. Profits dropped a little over $\$ 36,000$ in 1955 , and went into a tailspin by 1958 , when the Authority lost $\$ 415,397$. INForarE, 1958, p. 12. By cutting back production the loss was reduced to a little more than $\$ 220,000$ in 1959 , but in 1960 the loss had increased to more than $\$ 330,000$. INFORME, 1960, p. 12. The Iand Authority has offered no official explanation, but apparently production costs simply got out of hand. A labor shortage, coupled with a failure to mechanize, a pinch of inclement weather, and several dabs of mismanagement were the principal ingredients in the potpourri of increasing production costs.

Canning operations have been a separate source of continual losses for the Land Authority. Though it invested more than $\$ 3,500,000$ in 1957 in a new pineapple cannery in Barceloneta, it lost $\$ 837,650$ on the canning phase of its pineapple program in 1958. INFORARE, 1959, p. 15.

116. In 1961 the Authority leased its Barceloneta cannery to Stokely Van Camp, Inc. for 15 years under a 50-50 profit and loss sharing arrangement; the Authority to provide the pineapples, Stokely to provide the management and marketing organization. There is a complex allowed-costs formula allocating to each party the expenses of the joint venture. The Authority entered into the arrangement to capitalize orr Stokely's expertise and sales organization, hoping to turn pineapple production into a profitable commercial enterprise for Puerto Rico. Personal Interview with Héctor Bayrón-Montalvo, Planning Director of the Land Authority, Jan. 4, 1963.

117. By 1956 the Authority had invested a little more than $\$ 1,300,000$ in 2150 head of dairy cattle and 5260 head of beef cattle. INFORAIE, 1956, p. 24. The dairy program, in which milk and milk products were sold locally, was discontinued in 1958 when Puerto Rico's thriving dairy industry made the Authority's program superfuous. The beef program has been continued, however. Numerous experiments have been conducted with different breeds and with cross breeding to determine which types of cattle fared best in Puerto Rican environment. Calves were oftern sold for meat or to local farmers to build up their herds. The aim of the Authority is to improve the Puerto Rican cattle industry by breeding improved stocks and selling them to farmers. The Authority has presently assigned some 17,000 cuerdas to its cattle program and owns more than 10,000 head of cattle. This should prove to be one of the most important of the Authority's programs in the future. 
lands; ${ }^{118}$ fruit tree experiments; ${ }^{119}$ fertilizer production and distribution; ${ }^{120}$ improvement of cane seed $;^{121}$ hydroponic farming $; 122$ and the operation of machinery centers where small farmers may rent equipment. ${ }^{123}$

Thus, the Land Authority has been transformed from a vigorous instrumentality for breaking up large sugar latifundia into an instrumentality for stimulating growth and development through new agricultural industries. More and more the Authority has asked private entrepreneurs to assume projects that it had begun or to assist it in operating projects it has retained.124 The antagonism towards the large sugar corporations has largely disappeared, and

118. Through 1960 the Authority has spent $\$ 3,330,388$ in reclaiming 6,500 acres, through several drainage projects. INFORArE, 1960, p. 22.

119. In 1956 the legislature appropriated $\$ 10,000$ to the Authority to establish a nursery for citrus trees, mangos, and avocados. In co-operation with the Puerto Rican Forest Service, the Authority also began in 1956 a program of grafting fruit trees and selling them to local farmers. INFORME, 1956, p. 25.

120. In 1955 a program for the production and distribution of calcium carbonate to correct soil acidity was transferred to the Authority from the Conservation Bureau. The Authority now runs four mines and sells calcium carbonate to farmers at less than production costs. INFORME, 1960, p. 18.

121. Arr appropriation of 50,000 was made to the Authority in 1956 to carry out a program for the production and distribution of improved varieties of sugar cane seed. The legislature felt that unless farmers were persuaded to replant their cane fields, Puerto Rico would continue to be unable to meet its sugar quotas. The Authority co-operated with the University of Puerto Rico's Agricultural Experiment Station to conduct research on new varieties of cane seed, and by the end of 1960 the Authority had sold more than 5000 tons of seed at two-thirds its cost of production. $I d$. at 19.

122. $\$ 270,000$ was invested in an experimental hydroponic farm. This farm uses no soil for cultivation; seeds are planted in gravel beds into which chemical nutrients are fed. Yields per acre (in terms of the land occupied by the beds) can be enormously improved, for the plants can be kept much closer together, the nutrient formula can be regulated to give the plants optimum nourishment, and several crops can be harvested in a single year. The Authority never was able to make a go of the farm and lost money each year. In August of 1962 it was rented to two American entrepreneurs, who presently have about 15 acres under cultivation. Personal Interview with Héctor Bayrón-Montalvo, Planning Director of the Land Authority, Jan. 4, 1963.

123. The Land Authority has established four machinery centers where small farmers who cannot afford to buy machinery can rent it. Rental costs are fixed at a little less than half the charge the centers should make to break even. The losses are financed by legislative appropriations. INFORME, 1960, p. 17.

The purposes of these centers is not only to aid farmers by renting them machinery, but also to introduce the farmers to the advantages of mechanization. In addition to the rental centers, the Authority maintains two machinery repair centers, where it repairs all the machinery rented to the proportional profit farms and the private farmers.

124. For example, in 1961 Central Aquirre Sugar Company, one of Puerto Rico's largest sugar companies and a conspicuous violator of the 500 Acre Law, contracted with the Land Authority to provide technical, consulting, and other services at one of the Authority's sugar-mills. Standard \& Poor's Corporations 4870 (1962). 
the Authority itself has been forced to assume many of the characteristics of a large sugar corporation in the operation of its proportional profit farms. ${ }^{125}$

In Puerto Rico, then, politicians originally devoted to a program of land fragmentation and redistribution seeking both political and economic goals have largely withdrawn from their program, recognizing both its political expendability and its economic insufficiency as a core program of development, to concentrate governmental efforts in the development of new industry. Many factors contributing to the success of this shift in emphasis are unique to Puerto Rico and the special status she enjoys with the United States. Not only are Puerto Rican businesses within the United States tariff wall, but Puerto Rico has been able to offer sizeable reductions in United States as well as insular taxes. Political stability and security against expropriation also flow from the relationship with the United States and its legal system. Nationalistic hostility to foreign-owned and dominated industry has not been an important force in Puerto Rico since the battle with the sugar industry was fought and won. And the availability of unrestricted migration to the United States has enabled Puerto Rico to keep its population relatively constant, with the result that benefits of economic development are spread over a narrower population base.

But in assessing the relevance of Puerto Rico's experience to Latin America, it is significant that several important factors which threatened to curb Puerto Rico's economic growth are rarely encountered or may be avoided in most Latin American nations. The island had none of the natural advantages that typically generate industrial growth. There were almost no mineral resources, few skilled workers and little power. Puerto Rico is far from mainland markets and supplies, and unable to protect local markets from United States competition. Many Latin American nations have the natural advantages Puerto Rico lacks. Other measures are available to Latin America to encourage further industrialization. The substantial sums available through the Alliance for Progress may be used to attract or stimulate capital much as meaningful tax incentives were used in Puerto Rico. Reduction of the substantial overhead imposed by military expenditures may secure additional funds for development. A lessening of Latin proclivity for expropriation of foreign investments may help generate a good deal of private investment. And, while politically difficult in Catholic nations, encouragement of birth control could offer an effective restraint on mushrooming population growth.

Even if necessary politically, land tenure reform alone is by no means a panacea for Latin American economic ills. Questions of balance are presented: how much and what kind of agrarian reform is necessary and desirable? how much industrialization is possible in how short a time? which should be given more stress? While in some situations movement toward the Jeffersonian ideal through the creation of family farms may be politically expedient, it may also be economically undesirable. And in overpopulated areas with efficient

125. Padilla Seda, supra note 71 , at 312 . 
latifundia, where the landless agricultural worker is really a rural factory worker, redistribution of land into family farm units may be politically unnecessary, while threatening to lower production substantially. Even where the political pressure for land reform cannot be ignored, counter-considerations will suggest a strong attempt to control them. The flow of domestic and foreign capital required for industrial expansion may be inhibited by a vigorous campaign of expropriation, particularly if full compensation is not immediately forthcoming. And from the perspective of the typical private investor, who draws little distinction between different types of expropriation, though it is agricultural land expropriated today, it could just as easily be a factory tomorrow.

In assessing the utility of the Puerto Rican experience, it is important to remember Latin American nations lack the political and economic stability found in Puerto Rico. The constant danger of inflation only emphasizes the desirability of land as a long-term asset to be held at all costs. ${ }^{126}$ Land is often an important symbol to politicians of the right and the left, and a vigorous program of tenurial reform could catalyze unfortunate reactions. ${ }^{127}$ But the history of agrarian reform in Puerto Rico indicates that it may be possible to divert demands for land reform by curbing the political power and the abuses of that power by the latifundistas, and by increasing economic growth and opportunity through accelerated industrial development. The distribution of small plots in rural communities as Puerto Rico did for its agregados can also be an important technique for diverting pressures for full-scale agrarian reform. And resettlement may also provide potential industrial sites if training programs in mechanical skills are then undertaken. To be sure, some land reform may be necessary as a step in curbing the political power of the latifundistas. And in some areas, the political barometer may forecast that rural unrest can be mollified only by full-scale land redistribution. But in many areas, it may be possible to compromise the competing interest of the latifundistas and the rural workers with an imaginative program of limited agrarian reform.

KeItr S. Rosenn†

126. See Raushenbush, op. cit. supra note 1 , at 49.

127. Ibid.; Carroll, Land Reform as an Explosive Force in Latin-America, supra note 2 , at 4 .

†LL.B. 1963 Yale University. 